\title{
Seed germination capability of four endemic species in the Central Apennines (Italy): relationships with seed size
}

\author{
Anna Rita Frattaroli (*), Luciano Di Martino (**), Valter Di Cecco (*), \\ Rosangela Catoni (***), Laura Varone (***), Marco Di Santo (**) \& \\ Loretta Gratani (***)
}

\begin{abstract}
Frattaroli, A.R., Di Martino, L., Di Cecco, V., Catoni, R., Varone, L., Di Santo, M. \& Gratani, L. Seed germination capability of four endemic species in the Central Apennines (Italy): relationships with seed size. Lazaroa 34: 43-53 (2013).

Seed germination capability of Adonis distorta, Androsace mathildae, Aquilegia magellensis and Campanula fragilis subsp. cavolinii endemic species of the Central Apennines (Italy) were analyzed. Seed traits varied significantly among the considered species. In particular, seed volume was the largest in Adonis $\left(91.642 \pm 16.851 \mathrm{~mm}^{3}\right)$ and the lowest in Campanula $\left(0.029 \pm 0.008 \mathrm{~mm}^{3}\right)$. The seed coat thickness ranged from $31 \pm 10 \mu \mathrm{m}$ in Adonis to $9 \pm 1 \mu \mathrm{m}$ in Campanula. Pretreatments were carried out to improve seed germination. Seed germination did not happen in Adonis and Androsace in response to the applied treatments (i.e., 0, 250, $500 \mathrm{ppm}$ gibberelic acid, GA3) and the cold-wet stratification. A $65 \%$ increase of germination was observed after the pre-treatment with 500 ppm GA3 in Aquilegia which could be justified by an endogenous non-deep physiological dormancy. The final germination percentage increased by $26 \%$ in Aquilegia and decreased by $89 \%$ in Campanula after the cold-wet stratification treatment. The obtained results were used to define germination protocols which could be used in reinforcement projects for the wild populations of the considered endemic species as a means of reducing their extinction risk.
\end{abstract}

Keywords: endemics, seed germination, seed size, seed dormancy.

Resumen: Frattaroli, A.R., Di Martino, L., Di Cecco, V., Catoni, R., Varone, L., Di Santo, M. \& Gratani, L. Capacidad germinativa de especies endémicas de los Apeninos centrales (Italia): relaciones con el tamaño de la semilla. Lazaroa 34: 43-53 (2013).

En este trabajo se ha analizado la capacidad germinativa de cuatro especies endémicas de los Apeninos centrales: Adonis distorta, Androsace mathildae, Aquilegia magellensis y Campanula fragilis subsp. cavolinii. Los rangos de las semillas variaron significativamente entre las especies, particularmente se encontró que el volumen de semillas en Adonis (91.642 $\left.\pm 16.851 \mathrm{~mm}^{3}\right)$ era el más alto y en Campanula el más bajo $\left(0.029 \pm 0.008 \mathrm{~mm}^{3}\right)$. El grosor de la cubierta seminal se encontraba desde $31 \pm 10 \mu \mathrm{m}$ en Adonis hasta $9 \pm 1 \mu \mathrm{m}$ en Campanula. Se realizaron algunos pretratamientos para mejorar la germinación como fue la adición de distintas concentraciones de ácido giberélico (i.e., 0, 250, 500 ppm gibberelic acid, GA3) o la estratificación frío-caliente. Sin embargo no detectamos germinación ni en Adonis ni en Androsace. En el caso de Aquilegia se observó un aumento del $65 \%$ de la germinación después de pretratarla con 500 ppm GA, lo cual queda justificado por una dormancia fisiológica endógena no muy profunda. El porcentaje de germinación final se incrementó en Aquilegia en un 26\%, mientras que decreció un $89 \%$ en Campanula después del tratamiento de estratificación frío-caliente. Los resultados obtenidos fueron utilizados para definir los protocolos que deben ser utilizados para mejorar la conservación de especies endémicas en riesgo de extinción.

Palabras clave: especies endémicas, germinación, tamaño de semilla, dormancia

\footnotetext{
* Department of Life Health and Environmental Sciences. University of L'Aquila. Via Vetoio loc. Coppito. 67100, L'Aquila, Italy.

** Majella Seed Bank. Majella National Park. loc. Colle Madonna. 66010, Lama dei Peligni (CH), Italy.

*** Department of Environmental Biology. Sapienza University of Rome. P.le A. Moro, 500185 Rome, Italy. Corresponding author: Loretta Gratani. Fax: 0649912358. Email: loretta.gratani@uniroma1.it
} 


\section{INTRODUCTION}

Knowledge of rare species life-cycle and reproductive traits is essential for identifying limits to population growth and persistence (BEVILL \& LOUDA, 1999) especially in threatened wild species. Seed germination is a critical stage for the establishment of the plant (YousseF \& al., 2012) as its success is determinant for plant species propagation (RAJJOU \& al., 2012). Each species has specific requirements for seed germination (HARPER \& al., 1970; Meyer \& Monsen, 1991; SCHÜTZ \& MilBERG, 1997) which involves particular features of seed and environmental factors (BASKIN \& BASKIN, 1998). Many authors (JAKOBSSON \& ERIKSSON, 2000; BONITO \& al., 2011; LÖNNBERG \& ERIKSSON, 2013) underline the relationship between seed germination and seed size. Seed size represents the amount of maternal investment in the individual offspring (LEISHMAN \& al., 2000). Generally, large seeds have a greater germination success than small seeds (Pizo \& al., 2006). Seed coat plays an important role in embryo nutrition during seed development and against detrimental agents from the environment (MOHAMED-YASSEEN \& al., 1994; Weber \& al., 1996). Seed coat-imposed dormancy is part of the seed survival strategy of many species (WERKER, 1981; Kelly \& al., 1992; SchÜTZ, 2000). Moreover, seed coat exerts a germination-restrictive action most of the time by being impermeable to water and/or oxygen or by its mechanical resistance to radical protrusion. Seed dormancy is a trait that has been acquired by many species through selection for the ability to survive in unfavourable environments (BEWLWY \& al., 2013). Seed dormancy can be viewed as an adaptive mechanism for survival in a seasonally variable environment (WeSTOBY, 1981). Under natural conditions, dormant seeds are exposed to changes in environmental factors (e.g. light, temperature, moisture) which lead to cyclical changes in the dormancy state (FINKELSTEIN \& al., 2008). Many high mountain plants produce seeds with different types of dormancy to avoid germination in the year of seed dispersal and favour rapid emergence after snowmelt (BILLINGS \& MoONEY, 1968; BASKIN \& BASKIN, 1998; SHIMONO \& KUdO, 2005).
Several germination traits have been claimed to be specific to high-altitude species (i.e. rapid onset of germination after snowmelt and high seed viability; GimÉneZ-Benavides \& Milla, 2013).

Endemic species are a significant feature of the Mediterranean mountains (GÓMEZ-CAMPO, 1985; VÄre \& al., 2003; SAÍNZ \& Moreno, 2002; GAVILÁN \& al., 2002; EsCRIBÁ \& al., 2007; FUENTE $\&$ al., 2011) because of the high number of speciation events that have occurred (MARTín-BRAVO \& al., 2010). Mediterranean mountains are characterized by a high genetic diversity with many populations being genetically unique (RuIz-LABOURDETTE \& al., 2012). Predictions of climate change indicate that this genetic diversity could be disturbed significantly in the future (THUILLER \& al., 2005). Moreover, Mediterranean mountains are considered one of the most threatened ecosystems in the European Union (GómEZCAMPO, 1987; European Community, 1992). Thus, many efforts should be addressed to improve the conservation strategies for Mediterranean mountain species considering that the survival of endemic and threatened species is based on different and complementary conservation approaches and techniques (IUCN, 2002). The definition of germination protocols, in particular for species characterized by small populations and for which data are missing, could be an important step in this direction.

The aim of this work focused on seed germination capability of four endemic species growing in the Central Apennines, in Italy. In particular, we analysed the influence of different pre-treatments on seed germination for Adonis distorta Ten., Androsace mathildae Levier, Aquilegia magellensis F. Conti \& Soldano and Campanula fragilis Cirillo subsp. cavolinii (Ten.) Damboldt. The results may be used for conservation projects of the wild populations of these endemic species.

\section{MATERIALS AND METHODS}

\section{STUDY SITE AND SPECIES}

Experiments were carried out in the Majella Seed Bank within the Botanical Garden Michele 


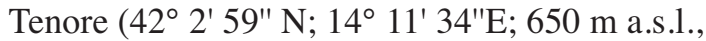
Italy) on seeds collected from the wild populations of Adonis distorta, Androsace mathildae, Aquilegia magellensis and Campanula fragilis subsp. cavolinii growing on Mount Majella. Hereafter, to facilitate reading, each species will be referred to the name of Genus. All the species are endemic of the Central Apennines and are included in the Regional Red List (CONTI \& al., 1997). In particular, Adonis (Ranunculaceae) grows in the Marche, Umbria, Lazio and Abruzzo regions (CONTI \& al., 2005) on high-altitude screes (2000-2500 m a.s.1.) characterized by small clasts (PignATTI, 1982). In Abruzzo, populations of few individuals grow in the Gran Sasso Massif, Velino Mount, Sirente Mount and Majella Mount. Adonis is included in the II and IV Annex of the Habitat Directive (Habitat Natura 2000) and categorized as DD (Data Deficient) in the IUCN Red List. Androsace (Primulaceae) is endemic of the Abruzzo region (CONTI \& al., 2005) where it grows at Gran Sasso Massif and Majella Mount (2500-2900 m a.s.l.) (PignAtTi, 1982) on cracks of limestone cliffs, mainly in the northern exposure. It is included in the II and IV Annex of the Habitat Directive (Habitat Natura 2000) and categorized as DD (Data Deficient) in the IUCN Red List. Aquilegia (Ranunculaceae) grows in Abruzzo and Molise regions (CONTI \& al., 2005) on dripping limestone walls from 1000 to $1500 \mathrm{~m}$ a.s.l. (Pignatti, 1982). Campanula (Campanulaceae) grows in Lazio, Abruzzo, Molise and Campania regions (ConTI \& al., 2005) on limestone cliffs from 200 to $1800 \mathrm{~m}$ a.s.l. (PignatTi, 1982). To date, there are no studies regarding the conservation strategies and seed germination capability of the selected species.

The climate of the Mount Majella, is characterized by a mean minimum air temperature $\left(\mathrm{T}_{\min }\right)$ of $-3.9 \pm 2.2^{\circ} \mathrm{C}$ (February), a mean maximum air temperature $\left(\mathrm{T}_{\max }\right)$ of $22.3 \pm 0.1{ }^{\circ} \mathrm{C}$ (July-August) and a mean annual air temperature $\left(\mathrm{T}_{\text {mean }}\right)$ of $7.6 \pm 6.5^{\circ} \mathrm{C}$. Total annual rainfall is $1343 \mathrm{~mm}$. Snow fallen from December to April (Meteorological Station of Passo Lanciano, Ch, $42^{\circ} 18^{\prime} 62^{\prime \prime} ; 14^{\circ} 09^{\prime} 87^{\prime \prime}$, data for the period 20002012, cetemps .aquila.infn.it).

\section{SEED COLLECTION}

Freshly-matured seeds of Adonis, Androsace, Aquilegia and Campanula were collected from the small wild populations growing on Mount Majella, from August to September 2010, in the fruiting period and immediately before dissemination, according to HAY \& SMITH (2003). The mother plants were randomly selected, according to Marshall \& Brown (1983) (Table 1). In particular, seeds of Adonis were collected at $2675 \mathrm{~m}$ a.s.l, on the north-northeast facing of Mount Focalone ( $\left.42^{\circ} 6^{\prime} 18^{\prime \prime} \mathrm{N} ; 14^{\circ} 7^{\prime} 10^{\prime \prime} \mathrm{E}\right)$; seeds of Androsace at $2760 \mathrm{~m}$ a.s.l. in the north facing of Mount Amaro (42 ${ }^{\circ} 12^{\prime \prime} \mathrm{N} ; 14^{\circ} 7^{\prime} 14^{\prime \prime} \mathrm{E}$ ); seeds of Aquilegia at $1225 \mathrm{~m}$ a.s.l on the south-west facing of the Eremo di San Giovanni $\left(42^{\circ} 9^{\prime} 14^{\prime \prime} \mathrm{N} ; 14^{\circ} 4^{\prime} 50^{\prime \prime}\right.$ E), and seeds of Campanula at $750 \mathrm{~m}$ a.s.l. in the north-east facing of Lama dei Peligni $\left(42^{\circ} 00^{\prime} 09^{\prime \prime}\right.$ $\left.\mathrm{N} ; 1^{\circ} 8^{\prime} 44^{\prime \prime} \mathrm{E}\right)$. Seeds ( $\mathrm{n}=300$ for Adonis, Androsace and Aquilegia; $\mathrm{n}=2000$ for Campanula) were immediately transported to the Botanical Garden.

Table 1

Characteristics of the considered species and of their natural environments at Mount Majella are shown. Abbreviations are: HScap., scapose hemicryptophyte; ChPulv., pulvinate chamaephyte; ChSuffr., suffruticose chamaephytes. Altitude (m.a.s.1.). End. App. Abr., Endemic Appenine Abruzzo; End. App. C., Endemic Appenine Campania.

\begin{tabular}{llllll}
\hline Species & Family & Life Form & Chorotype & Altitude & Exposure \\
\hline Androsacea mathildae & Primulaceae & ChPulv & End.App.Abr. & 2760. & NNE \\
Adonis distorta & Ranunculaceae & HScap & End.App.C. & 2675 & NNE \\
Aquilegia magellensis & Ranunculaceae & HScap & End.App.C. & 1225 & SW \\
Campanula fragilis subsp. cavolinii & Campanulaceae & ChSuffr & End.App.C. & 750 & NE \\
\hline
\end{tabular}




\section{SEED TRAITS MEASUREMENTS}

At the Majella Seed Bank seeds were surfacesterilized in a $1 \%$ sodium hypochlorite solution for 1-10 minutes, according to the seed coat type (BACCHETTA \& al., 2006), then rinsed in distilled water. The seed coat after the imbibition in distilled water was dried and then the experiment was carried out. Seeds were placed in paper bags at $5^{\circ} \mathrm{C}$ until the germination experiment started. Three groups of 100 seeds each for Adonis, Androsace and Aquilegia, and two groups of 1000 seeds each for Campanula (seeds $<0.010 \mathrm{mg}$ ) were weighed to measure seed fresh mass $\left(\mathrm{S}_{\mathrm{M}}\right)$, according to CERDÀ $\&$ GARCÍA-FAYOS (2002). The reduced number of seeds used was justified by the small number of the wild populations of the considered species in Majella National Park. In particular, there were few Adonis populations for a total number of ca. 1500 plants, and few Androsace populations for a total number of ca. 400 plants (non-published data from the Park). Despite Aquilegia being largely distributed in respect to the other two species (VAN GILS \& $a l ., 2012)$, there are no data about the number of populations and the number of plants per population. No data about number and size of populations are available for Campanula.

Seed length (L, longest axis), width ( $\mathrm{W}$, intermediate axis) and thickness ( $\mathrm{T}$, shortest axis) (20 seeds per species) were measured, according to CERDÀ \& GARCÍA-FAYOS (2002); from these data, seed surface $(\mathrm{S}=\mathrm{L} \times \mathrm{W})$, volume $(\mathrm{V}=\mathrm{L} \times \mathrm{W} \times$ $\mathrm{T}$ ), density $\left(\mathrm{D}=\mathrm{S}_{\mathrm{M}} / \mathrm{V}\right)$ and the ratio $\mathrm{S} / \mathrm{S}_{\mathrm{M}}$ (surface/mass) were calculated. To characterize seed shape, the Eccentricity Index $($ E.I. = L/W) was used (BAlkaya \& Odabas, 2002). Seed coat thickness was measured at 3 or 4 points of each seed by a stereo-microscope (Leica Wild M10), according to TUNJAI \& ELLIOTT (2012).

\section{GERMINATION EXPERIMENT}

The seed germination experiment was carried out on seeds of the considered species which were transferred to an agar medium ( $\left.7 \mathrm{~g} \mathrm{l}^{-1}\right)$ (MORGAN \& al., 1997). Media was integrated with $4.4 \mathrm{~g} \mathrm{l}^{-1}$ of Murashige Skoog salts (MS; Murashige \& SKOOG, 1962) because it provided nutrients to allow the seedlings growth (Pence, 1999). We followed this procedure because we wanted to cultivate the seedlings in the Botanical Garden and use them in reinforcement programs of wild populations in Majella National Park.

The $\mathrm{pH}$ was stabilized at 5.5 and autoclaved at $120{ }^{\circ} \mathrm{C}$ and $2 \mathrm{~atm}$ for $20 \mathrm{~min}$ (CERABOLINI \& al., 2004). Seeds were transferred to Petri dishes ( $90 \mathrm{x}$ $10 \mathrm{~mm}$ each) and sown under a laminar flow hood. Petri dishes were transferred to the growth chamber for 30-d incubation (BACCHETTA \& al., 2006). Germination tests were performed in a light and temperature controlled growth chamber (Angelantoni Ekoch 700 , Italy) at $20^{\circ} \mathrm{C}$ constant temperature and photoperiod of $12 \mathrm{~h}$ in the light and $12 \mathrm{~h}$ in the dark (BACCHETTA \& al., 2006). The chamber was equipped with cool-white fluorescent tubes providing a photon flux density (PFD) of $22 \mu \mathrm{mol}$ (photon) $\mathrm{m}^{-2} \mathrm{~s}^{-1}$. Seeds showing radicle emergence were recorded as 'germinated' (CôME, 1970).

The following treatments were carried out for the considered seed types: control treatment $(0 \mathrm{ppm}$ GA3 treatment); 250 ppm GA3treatment; 500 ppm GA3 treatment; cold-wet stratification treatment. Each of the considered treatments consisted of two replicate of 25 seeds each (CERABOLINI\& al. 2004) for Adonis, Androsace and Aquilegia, and 50 seeds for Campanula. The number of germinated seeds was counted every day for 30 days to evaluate the dynamics of germination, according to BACCHETTA $\&$ al. (2006). The low number of seeds per replicate and the low number of replicates in each experiment was due to the limited seeds availability because of the species were rare and there were few populations (MATTANA \& al., 2012).

\section{PRE-GERMINATION SEED TREATMENT}

Gibberellic acid (GA3)

Seeds were imbibed for $24 \mathrm{~h}$ in either $250 \mathrm{ppm}$ and $500 \mathrm{ppm}$ GA3 and distilled water $(0 \mathrm{ppm}$, control) (RODRÍGUEZ PÉREZ,1993).

\section{COLD-WET STRATIFICATION TREATMENT}

The seeds were subjected to a cold-wet stratification treatment to simulate chilling conditions under snow-pack typical of high elevation moun- 
tain areas (GimÉneZ-BenAVIDES \& Milla, 2013). The pots were filled with sand and soil and wetted with distilled water to ensure humid (BACCHETTA $\& a l ., 2006)$. The pots were wrapped in aluminium foil and stored in a refrigerator at $5{ }^{\circ} \mathrm{C}$ for 3 months before germination tests. The refrigerator (Angelantoni EKOFRIGOLAB 1500) was equipped with a display that show continuously the temperature inside, and a microprocessor control system with audible and visual alarm systems.

The cold-wet treatment was extended up to 9 months for Adonis and Androsace seeds.

\section{DATA ANALYSIS}

The dynamics of germination was determined by the Weibull function (WeIBULL, 1951; JOHNSON \& KOTZ, 1970) from the following formula:

$$
\mathrm{y}=\mathrm{M}\{1-\mathrm{e}[\mathrm{k}(\mathrm{t}-\mathrm{z})] \mathrm{c}\}
$$

where $y$ was the germination percentage at time $t$ (days); $\mathrm{M}$ the final germination at $30 \mathrm{~d}$; $\mathrm{z}$ the germination delay; $\mathrm{c}$ the curve shape parameter (ranging from 0 to 3 ) obtained by optimising the sum of the squared differences.

The relative germination rate $(\mathrm{k})$ was determined from the following equation:

$$
\mathrm{k}=1 /\left(\mathrm{T}_{50}-\mathrm{z}\right)
$$

where $\mathrm{T}_{50}$ was the half-germination time (i.e. number of days in reaching $50 \%$ of final germination) calculated from the formula of COOLBEAR \& al. (1980) modified by THANOS \& Doussi (1995):

$$
\left.\mathrm{T}_{50}=\left[(\mathrm{N} / 2)-\mathrm{N}_{1}\right) \times\left(\mathrm{T}_{2}-\mathrm{T}_{1}\right)\right] / \mathrm{N}_{2}-\mathrm{N}_{1}
$$

where $\mathrm{N}$ was the final percentage of germinated seeds; $\mathrm{N}_{1}$ the percentage of seeds germinated slightly lower than $\mathrm{N} / 2 ; \mathrm{N}_{2}$ the percentage of seeds germinated slightly higher than $\mathrm{N} / 2 ; \mathrm{T}_{1}$ the number of days that correspond to $\mathrm{N}_{1} ; \mathrm{T}_{2}$ the number of days that correspond to $\mathrm{N}_{2}$.

Pearson's correlation analysis was performed to evaluate the correlation among the considered seed traits (L, W, T, S, V, D, Ratio S/S $\mathrm{S}_{\mathrm{M}}$, E.I.).

One way ANOVA was performed to analyze differences in seed traits among the considered species followed by a post-hoc Tukey's test to compare differences among means (Statistica, Stasoft, USA). Moreover, in order to test the interactive effect of the treatments and species on $\mathrm{M}, \mathrm{T}_{50}$ and $\mathrm{z}$, a $2 \times 4$ factorial design was performed by a generalized linear model (GLM) in R (R Development Core Team, 2011).

\section{RESULTS}

\section{SIZE SEED}

Seed traits of the considered species are shown in table 2. L ranged from $7.1 \pm 0.4 \mathrm{~mm}$ in Adonis to $0.5 \pm 0.1 \mathrm{~mm}$ in Campanula. W ranged from $3.92 \pm 0.55$ (Adonis) to $0.24 \pm 0.02 \mathrm{~mm}$ (Campanula) and $\mathrm{T}$ from $3.31 \pm 0.30 \mathrm{~mm}$ (Adonis) to 0.24 $\pm 0.02 \mathrm{~mm}$ (Campanula). $\mathrm{S}$ varied from $0.12 \pm 0.02$ $\mathrm{mm}^{2}$ in Campanula to $27.62 \pm 4.68 \mathrm{~mm}^{2}$ in Adonis and V from $0.029 \pm 0.008 \mathrm{~mm}^{3}$ in Campanula and to $91.642 \pm 16.85 \mathrm{~mm}^{3}$ in Adonis. The mean value of D was $0.45 \pm 0.16 \mathrm{mg} \mathrm{mm}^{-3}$ with Androsace having the highest value $\left(0.62 \pm 0.10 \mathrm{mg} \mathrm{mm}^{-3}\right)$ and Adonis the lowest one $\left(0.30 \pm 0.05 \mathrm{mg} \mathrm{mm}^{-3}\right)$.

Table 2

Seed traits of the studied species

Abbreviations are: L, length; W, weight; T, thickness; S, surface; V, volume; D, density; Ratio S/SM, ratio

\begin{tabular}{|c|c|c|c|c|c|c|c|c|c|}
\hline Species & $\begin{array}{c}\mathrm{L} \\
(\mathrm{mm})\end{array}$ & $\begin{array}{c}\mathrm{W} \\
(\mathrm{mm})\end{array}$ & $\begin{array}{c}\mathrm{T} \\
(\mathrm{mm})\end{array}$ & $\begin{array}{c}\mathrm{S} \\
\left(\mathrm{mm}^{2}\right)\end{array}$ & $\begin{array}{c}\mathrm{V} \\
\left(\mathrm{mm}^{3}\right)\end{array}$ & $\begin{array}{c}\mathrm{D} \\
\left(\mathrm{mg} \mathrm{mm}^{-3}\right)\end{array}$ & $\begin{array}{l}\text { Ratio S/ } \\
\mathrm{S}_{\mathrm{M}}\end{array}$ & E.I. & $\begin{array}{c}\text { Seed coat } \\
\mathrm{T}(\mu \mathrm{m})\end{array}$ \\
\hline Adonis distorta & $7.1 \pm 0.4 \mathrm{a}$ & $3.92 \pm 0.55 \mathrm{a}$ & $3.31 \pm 0.30 \mathrm{a}$ & $27.62 \pm 4.68 \mathrm{a}$ & $91.642 \pm 16.851 \mathrm{a}$ & $0.30 \pm 0.05 \mathrm{a}$ & $1.0 \pm 0.2 \mathrm{a}$ & $1.82 \pm 0.24 a$ & $31 \pm 10 \mathrm{a}$ \\
\hline Androsacea mathildae & $2.3 \pm 0.2 b$ & $1.52 \pm 0.14 \mathrm{~b}$ & $0.70 \pm 0.06 \mathrm{~b}$ & $3.53 \pm 0.54 b$ & $2.486 \pm 0.49 \mathrm{~b}$ & $0.62 \pm 0.10 \mathrm{~b}$ & $2.4 \pm 0.4 \mathrm{~b}$ & $1.52 \pm 0.11 \mathrm{~b}$ & $27 \pm 5 a$ \\
\hline Aquilegia magellensis & $1.9 \pm 0.1 \mathrm{~b}$ & $0.88 \pm 0.07 \mathrm{c}$ & $0.79 \pm 0.07 \mathrm{~b}$ & $1.64 \pm 0.16 \mathrm{c}$ & $1.298 \pm 0.169 \mathrm{c}$ & $0.56 \pm 0.07 b$ & $2.3 \pm 0.2 b$ & $2.12 \pm 0.23 \mathrm{c}$ & $26 \pm 2 a$ \\
\hline $\begin{array}{l}\text { Campanula fragilis } \\
\text { subsp. cavolinii }\end{array}$ & $0.5 \pm 0.1 \mathrm{c}$ & $0.24 \pm 0.02 \mathrm{~d}$ & $0.24 \pm 0.01 \mathrm{c}$ & $0.12 \pm 0.02 \mathrm{~d}$ & $0.029 \pm 0.008 \mathrm{~d}$ & $0.33 \pm 0.08 \mathrm{a}$ & $13.2 \pm 2.5 \mathrm{c}$ & $2.04 \pm 0.18 \mathrm{ac}$ & $9 \pm 1 b$ \\
\hline
\end{tabular}
surface/ mass; E.I., Eccentricity Index; mean \pm st.dev, $n=20$. Within each column mean with the same letter are not significantly different (ANOVA, Tuckey test, $\mathrm{p}>0.05$ ). 
Table 3

Results of the Pearson's correlation analysis among the considered seed variables. Abbreviations are: Ratio $\mathrm{S} / \mathrm{S}_{\mathrm{M}}$, Ratio surface/ mass; E.I., Eccentricity Index. Bold type indicate significant correlation $(\mathrm{P}<0.05)$.

\begin{tabular}{|c|c|c|c|c|c|c|c|}
\hline & Weight & Thickness & Surface & Volume & Density & Ratio $S / S_{M}$ & E.I. \\
\hline Length & 0.995 & 0.992 & 0.984 & 0.968 & -0.644 & -0.500 & -0.286 \\
\hline Weight & & 0.975 & 0.975 & 0.952 & -0.652 & -0.472 & -0.381 \\
\hline Thickness & & & 0.993 & 0.988 & -0.576 & -0.582 & -0.172 \\
\hline Surface & & & & 0.996 & -0.500 & -0.644 & -0.218 \\
\hline Volume & & & & & -0.440 & -0.698 & -0.147 \\
\hline Density & & & & & & -0.334 & 0.392 \\
\hline Ratio $\mathrm{S} / \mathrm{S}_{\mathrm{M}}$ & & & & & & & -0.203 \\
\hline E.I. & & & & & & & \\
\hline
\end{tabular}

The significantly highest $(\mathrm{p}<0.05) \mathrm{S} / \mathrm{S}_{\mathrm{M}}$ ratio was found in Campanula (13.2 \pm 2.5$)$ and the lowest ratio in Adonis $(1.0 \pm 0.2)$. As regards to seed shape, E.I. ranged from $1.52 \pm 0.11$ in $A n$ drosace to $2.12 \pm 0.23$ in Aquilegia. The seed coat thickness was $31 \pm 10 \mu \mathrm{m}$ in, Adonis, $26 \pm 2 \mu \mathrm{m}$ in Aquilegia, $27 \pm 5 \mu \mathrm{m}$ in Androsace and $9 \pm 1$ $\mu \mathrm{m}$. in Campanula.

A significant correlation was verified among L, W, T, S and V (Table 3).

\section{SEED GERMINATION DYNAMIC}

The seed germination dynamic of Aquilegia and Campanula in the control treatment and after 250 ppm GA3, 500 ppm GA3 and cold-wet treatments are shown in figure 1 . Values of $\mathrm{M}, \mathrm{T}_{50}$ and $\mathrm{z}$ for Aquilegia and Campanula are show in figure 2.

\section{CONTROL TREATMENT}

In the control treatment $\mathrm{M}$ was $46 \pm 8 \%$ and $93 \pm 1 \%$ in Aquilegia and Campanula, respectively, $\mathrm{T}_{50}$ was $12 \pm 0$ and $5.5 \pm 0.7$ days in Aquilegia and Campanula, respectively. The $\mathrm{z}$ was 9 \pm 1 days in Aquilegia and the final germination took place 20 days after sowing, while in Campanula $\mathrm{z}$ was $3 \pm 0$ days and the final germination took place 20 days after sowing. In Adonis and Androsace $\mathrm{M}$ was $0 \%$.

\section{PPM GA3 TREATMENTS}

Compared with the control $\mathrm{M}$ increased by $35 \%$ and $1 \%$ in Aquilegia and Campanula when the 250 ppm GA3 treatment was applied. The final germination took place 30 and 26 days after sowing, respectively. With respect to the control, $\mathrm{T}_{50}$ decreased by $4 \%$ in Aquilegia while in Campanula it did not vary significantly. In Aquilegia
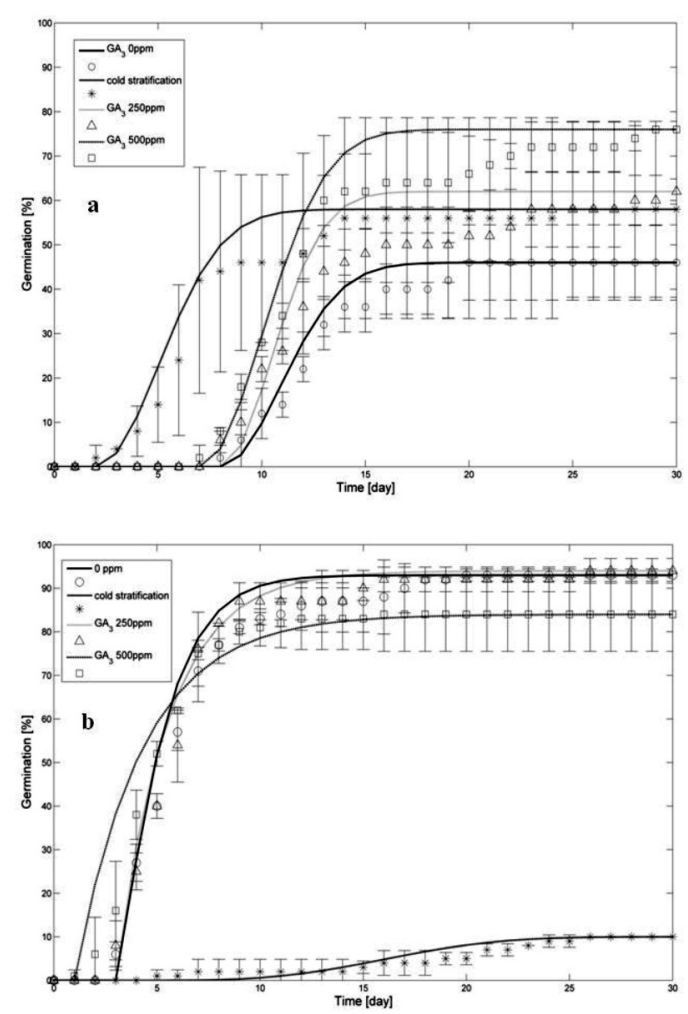

Figure 1. - Germination trend in seeds of Aquilegia (a) and Campanula (b) in the control treatment, $250 \mathrm{ppm}$ GA3 treatment, 500 ppm GA3 treatment and cold-wet treatment. Continuous and dashed lines show fitted Weibull functions which was calculated using germination parameters. 


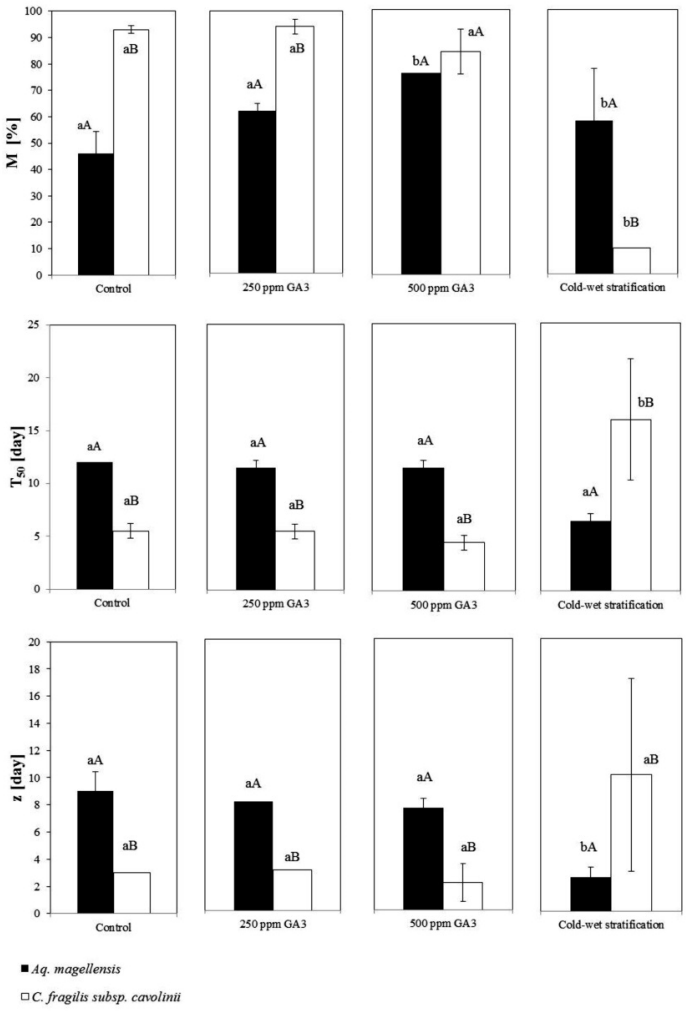

Figure 2. - Percentage of the final germination (M), half-germination time (T50) and germination delay (z) for Aquilegia and Campanula. Mean with the same letters are not significantly different (result of GLM model). For each parameter lowercase letters indicate the intra-specific different in each treatment and capital letters indicate the inter-specific different in each treatments.

and Campanula, $\mathrm{z}$ was $8 \pm 0$ and $3 \pm 0$ days, respectively. In Adonis and Androsace M was $0 \%$ after the treatment.

\section{PPM GA3 TREATMENTS}

After 500 ppm GA3 treatment, $M$ increased by $65 \%$ in Aquilegia compared to the control, while it decreased by $10 \%$ in Campanula. The final germination took place 28 and 16 days after sowing, respectively. $\mathrm{T}_{50}$ was $11 \pm 0$ and $4.5 \pm 0.7$ days in Aquilegia and Campanula, respectively. In Aquilegia and Campanula, z was $7.5 \pm 0.7$ and $2 \pm 1$ days, respectively. In Adonis and in Androsace M was $0 \%$ after the treatment.

\section{COLD- WET STRATIFICATION}

In the cold-wet stratification treatment $\mathrm{M}$ increased by $26 \%$ in Aquilegia while it decreased by $89 \%$ in Campanula compared to the control. The final germination happened 25 and 26 days after sowing, respectively. $\mathrm{T}_{50}$ decreased by $46 \%$ in Aquilegia with respect to the control while it increased more than $100 \%$ in Campanula. Results also showed that $\mathrm{z}$ was $2.5 \pm 0.7$ and $10 \pm 7$ days, respectively. In Adonis and Androsace $\mathrm{M}$ was $0 \%$ after the treatment. A low $\mathrm{M}(<10 \%)$ was observed 9 months after the cold-wet treatment.

\section{DISCUSSION}

On the whole, the results of this study show significant differences in seed traits and germination capability in response to the considered treatments among the species.

The Pearson's correlation analysis underlines a significant correlation among L, W, T, S, V and D.

In particular, $\mathrm{L}, \mathrm{W}, \mathrm{T}, \mathrm{S}$ and $\mathrm{V}$ are the largest in Adonis and the lowest in Campanula, while in Androsace and Aquilegia have intermediate values. KiKuZAWA \& Koyama (1999) underline that small seeds have a faster water absorption capacity than large seeds, since they have a larger surface area to mass ratio. Our results underline that $\mathrm{S} / \mathrm{S}_{\mathrm{M}}$ ratio is the highest in Campanula $(13.25 \pm$ 2.5) and the lowest in Adonis (1.03 \pm 0.17$)$.

As concerns germination it does not occur in Adonis and Androsace in response to treatments (control treatment, GA3 treatment, cold-wet treatment). Nevertheless, increasing the time of coldwet stratification from three to nine months, the germination capability is below $10 \%$. This result suggests that seeds from higher altitudes, such as Androsace, have a stronger dormancy than those from lower altitudes (i.e. Aquilegia and Campanula). We hypothesize that Androsace seeds have a deep physiological dormancy (sensu NikOLAEVA, 1969) because dormancy is not completely broken by the stratification treatment. The same results are obtained for Adonis, in agreement with those of GODEFROID \& al. (2010) for other species of the same genus, who underline the lack of kno- 
wledge with regard to germination and dormancy for rare and threatened species. A morphological dormancy cannot be excluded for Adonis and Androsace; in particular, Adonis belonging to Ranunculaceae family is characterized by a rudimentary underdeveloped embryo of mature seeds (MARTIN, 1946; Finch-Savage \& Leubner-MetzGer, 2006), while Androsace is characterized by a linear underdeveloped embryo of mature seeds (MARTin, 1946; Finch-SAVAGE \& LeUbner-MetZGER, 2006). The presence of an underdeveloped embryo of mature seeds suggests for these species both a morphological and physiological dormancy according to BASKIN \& BASKIN (2004), FINCH-SAVAGE \& LEUBNER-METZGER (2006). Nevertheless, in the present study we have not investigated this type of dormancy because a large amount of seeds would have been necessary, and considering that CRAWFORD \& al. (2007) suggest that only one germination treatment should be done when there are small seed amounts available for endemic species. Thus, in this case it is important to define an efficient protocol to enhance the germination success (GODEFROID \& al., 2010).

Our results underline that treatment, species and their interaction significantly affect $\mathrm{M}, \mathrm{T}_{50}$ and $\mathrm{z}$ as shown by GLM analysis. In particular, the interaction effect between treatment and species on $\mathrm{M}$ differs significantly for cold $(\mathrm{t}=-0.072$, $\mathrm{p}<0.001)$ and $500 \mathrm{ppm} \mathrm{GA3}(\mathrm{t}=-3.314, \mathrm{p}<0.01)$. With regards to $T_{50}$ and $z$, the interaction effect between treatment and species differ significantly only for the cold-wet treatment $(\mathrm{t}=7.260, \mathrm{p}<$ 0.01 and $\mathrm{t}=4.095, \mathrm{p}<0.05$, respectively).

DEBEAUJON \& KOORNNEEF (2000) show the role of gibberellins in promoting seed germination. Exogenous application of GA3 overcomes seed dormancy in several species (BASKIN \& BASKIN, 1998) promoting germination in some species that normally require cold stratification, light, or afterripening (BEWLWY \& al., 1994). GA promotes the production of enzymes such as endo-b-mannanase, which loosen cell walls in the endosperm, thereby reducing resistance to radicle emergence (BEwlwy, 1997; GROOT \& KARSSEN, 1987; YAMAGUCHI \& KAMIYA, 2002). Nevertheless, our results underline a different behaviour for Aquilegia and Campanula in response to GA3 treatments. In par- ticular, Aquilegia is more responsive to GA3 treatments than Campanula which in turn shows a significant response only to the cold-wet treatment. In fact, the 500 ppm GA3 treatment increases the final germination by $65 \%$ in Aquilegia compared to the control and it can be justified by an endogenous non-deep physiological dormancy, according to the results of NiKOlaEva (1969). On the contrary, the 250 and 500 ppm GA3 treatments do not significantly affect the final germination in Campanula compared to the control.

Meyer \& Mosen (1991) suggest that populations normally encountering long periods with snow cover and adverse winter conditions require longer periods of cold stratification for germination than those exposed to milder winters. The cold-wet stratification improves germination in many high mountain species of eastern Europe and North America (BASKIN \& BASKIN, 1998) and it is indicative of a physiological dormancy (BASKIN \& BASKIN, 2005). Our results show a different response to the cold-wet treatment for the considered species. In particular, the $89 \%$ decrease in the final germination and the more $100 \%$ increase in the $\mathrm{T}_{50}$ more in Campanula compared to the control can be also related to the low seed size of as suggested by SCHLORHAUFER (2006) who underlines that small seeds are more subjected to viability loss. This result can be interpreted as an adaptive consequence of the short period of exposure to snow, considering that this species grows at $750 \mathrm{~m}$ a.s.l. and snow covers the soil only for 15 days for one month during the year. On the contrary, Adonis and Androsace grow at a higher altitude $(2675 \mathrm{~m}$ a.s.l. and $2760 \mathrm{~m}$ a.s.l., respectively) where snow persists for 7 to 9 months during the year. Moreover, the $93 \%$ germination percentage in the controls suggests a low level of physiological dormancy in Campanula, according to the results of GODEFROID $\&$ al. (2010) for the species of the same genus. This result shows that cold-wet treatment does not necessarily promote germination.

The observed differences in seed dormancy of the considered species could also be related to the seed coat thickness, as suggested by UUBANSKA \& al. (1979), ZUUR-ISLER (1982) and SCHÜTZ (2000). Seed coat thickness is larger in Adonis, Aquilegia and Androsace (28 \pm 3 , mean value) and the lo- 
west in Campanula $(9 \pm 1)$. Large-seeded species invest proportionately greater resources into physical defences, such as a thick endocarp or seed coat, in response to high predation risks (FenNer, 1983; Blate \& al., 1998; Moles \& al., 2003). Nevertheless, the presence of a thick seed coat may delay germination by limiting oxygen exchange or by acting as a physical constraint to embryo growth (NORDEN \& al., 2009).

Seed shape is an important determinant of seed dispersal, probable loss and moisture imbibitions (CERDÀ \& GARCÍA-FAYOS, 2002; BALKAVA \& ODABAS, 2002). The results show that seed shape is elliptic for Androsace, egg-shaped for Adonis and long-shaped for Aquilegia and Campanula. Differences in seed shape determine variations of the surface area that provides contact with the external environment (GRUNDY \& $a l ., 2003)$ and influence the response to burial depth in a different way. There is a significant correlation between the optimum emergence depth and seed shape (THOMPSON \& al., 1993) where small and rounded seeds tend to persist in soil, while large and elongate or flattened seeds are transient in the soil (THOMPSON \& al., 1994; BEKKER \& al., 1998). TTHOMPSON \& al. (1993) suggest that ease of burial and rates of predation could be the mechanism underlying the relations- hip between seed size and shape and persistence in the soil.

On the whole our results give information on the relationship between seed traits and germination capability of the considered endemic species underlining the importance of the selected treatments to favour germination capability. Thus, based on the obtained results, germination protocols for the considered species can be suggested. In particular, the germination protocol for Campanula forecasts seed imbibition for 24 hours in distilled water, then moving seeds to Petri dishes with agar medium $\left(7 \mathrm{~g} \mathrm{l}^{-1}\right)$ integrated with $4.4 \mathrm{~g} \mathrm{l}^{-1}$ of Murashige Skoog salts and $\mathrm{pH}$ stabilized at 5.5. Petri dishes must be put into the growth-chamber at $20^{\circ} \mathrm{C}$ with $12 / 12$ hour light and dark period.

With regards to Aquilegia, the protocol is the same as that for Campanula except carrying out the imbibition for 24 hours in 500 ppm GA rather than in distilled water.

We recommend a cold-wet treatment at least for 9 months to improve the germination capability for Adonis and Androsacea. Nevertheless, for these two species further research regarding their germination behaviour should be carried out. The recommended protocols may be used in reinforcement projects of the wild populations as a means of reducing the extinction risk of these endemic species.

\section{REFERENCES}

Bacchetta, G., Fenu, G., Mattana, E., Piotto, B., Virevaire, M. - 2006- Manuale per la raccolta, studio, conservazione e gestione ex situ del germoplasma - APAT. Ag. Prot. Amb. Serv. Tec.

Balkaya, A. \& Odabas, M.S. -2002-Determination of seed characteristics in some significant snap bean varieties grown in Samsun, Turkey - Pak. J. Biol. Sci. 5(4): 382-387.

Baskin, C.C. \& Baskin, J.M. (Eds.) -1998-Seeds: ecology, biogeography, and evolution of dormancy and germination - Academic Press, San Diego.

Baskin, J.M. \& Baskin, C.C. - 2004-A classification system for seed dormancy - Seed Sci. Res. 14: 1-16.

Baskin, C.C. \& Baskin, J.M. - 2005- Seed dormancy in wild flowers - In: McDonald, M.B. \& Kwong, F.Y. (Eds.). Flower seeds: Biology and technology. Pp. 163185. CABI Publ., Cambridge, MA.

Bekker, R.M., Bakker, J.P., Grandin, U., Kalamees, R., Milberg, P. - 1998 - Seed size, shape and vertical distribu- tion in the soil: indicators of seed longevity - Funct. Ecol. 12: 834-842.

Bevill, R.L. \& Louda, S.M. - 1999- Comparisons of related and common species in the study of plant rarity Cons. Biol. 13: 493-498.

Bewley, J. D. - 1997 - Seed germination and dormancy Plant Cell 9: 1055-1066.

Bewley, J. D. \& Black, M. (Eds.) - 1994 - Seeds: Physiology of development and germination - Plenum Press, New York.

Bewley J.D., Bradford, K., Hilhorst, H., Nonogaki, H. (Eds.) -2013 - Seeds: Physiology of Development, Germination and Dormancy, 3rd ed. - Springer, New York

Billings, W.D. \& Mooney, H.A. - 1968 - The ecology of arctic and alpine plants - Biol. Rev. 43: 481-529.

Blate, G.M. Peart, D. R. \& Leighton, M. -1998 - Postdispersal predation on isolated seeds: a comparative study of 40 tree species in a Southeast Asian rainforest - Oikos, 82: 522-538. 
Bonito, A., Varoni, L. \& Gratani, L. -2011 - Relationship between acorn size and seedling morphological and physiological traits of Quercus ilex L. from different climates - Photosynthetica 49(1): 75-86.

Cerabolini, B., De Andreis, R., Ceriani, R.M., Pierce, S. \& Raimondi, B. - 2004- Seed germination and conservation of endangered species from the Italian Alps: Physoplexis comosa and Primula glaucescens - Biol. Conserv. 117: 351-356.

Cerdà, A. \& García-Fayos, P. - 2002 - The influence of seed size and shape on their removal by water erosion - Catena 48: 293-301.

Côme, D. (Eds.) - 1970 - Les Obstacles a la Germination - Ed. Masson, Paris.

Conti, F., Manzi, A. \& Pedrotti, F. - 1997- Liste rosse regionali delle piante d'Italia - Soc. Bot. Ital., Ass. Ital. WWF, Camerino. 139 pp.

Conti, F., Abbate, G., Alessandrini, A., Blasi, C., Bonacquisti, S. \& Scassellati, E. - 2005- An annotated checklist of the Italian vascular flora - Palombi Ed., Roma.

Coolbear, P., Grierson, D. \& Heydecker, W. -1980- Osmotic pre-sowing treatments and nucleic acid accumulation in tomato seeds (Lycopersicon lycopersicum) Seed Sci. Technol. 8: 289-303.

Crawford, A.D. Steadman, K.J., Plummer, J.A., Cochrane, A., Probert, R.J. - 2007- Analysis of seed-bank data confirms suitability of international seed-storage standards for the Australian flora - Aust. J. Bot. 55:18 29.

Debeaujon, I \& Koornneef, M. - 2000 - Gibberellin requirement for Arabidopsis seed germination is determined both by testa characteristics and embryonic Abscisic Acid - Plant Physiol. 122: 415-424.

Escribá Baeza, M.C., Arregui, J.M. \& Laguna, E. -2007Germinación de Cistus heterophyllus Desf. subsp. carthaginensis (Pau) M.B. Crespo \& Mateo, taxon gravemente amenazado en la Comunidad Valenciana Lazaroa 28: 101-107.

European Community - 1992 - Conservation of natural habitats and of wild fauna and flora - Council Directive 92/43/EEC.

Fenner, M. - 1983 - Relationships between seed weight, ash content and seedling growth in twenty-four species of Compositae - New Phytol. 95: 697-706.

Finkelstein, R., Reeves, W., Ariizumi, T., Steber, C. 2008 - Molecular aspects of seed dormancy - Ann. Rev. Plant Biol. 59: 387- 415.

Finch-Savage, W.E. \& Leubner-Metzger, G. -2006- Seed dormancy and the control of germination - New Phytol. 171: 501-523.

Fuente, V., Rufo Nieto, L. \& Sánchez-Mata, D. -2011 Sarcocornia hispanica (Chenopodiaceae), a new species from the Iberian Peninsula - Lazaroa 32: 9-13.

Gavilán, R.G., Sánchez-Mata, D., Escudero, A., \& Rubio, A. - 2002- Spatial structure and interspecific interactions in Mediterranean high mountain vegetation (Sistema Central, Spain) - Isr. J. Plant Sci. 50: 217-228.
Giménez-Benavides, L. \& Milla, R. - 2013- Comparative germination ecology of two altitudinal vicariant $\mathrm{Sa}-$ xifraga species endemic to the north of Spain - Plant Biol. 15: 593-600.

Godefroid, S. \& al. -2010- Germination capacity and viability of threatened species collections in seed banks - Biodiv. Cons. 19: 1365-1383.

Gómez-Campo, C. - 1985- The Iberian Peninsula. Plant conservation in the Mediterranean area - Junk Publishers, Dordrecht.

Gómez-Campo, C. (Eds.) - 1987- Libro rojo de las especies vegetales amenazadas de España peninsular e Islas Baleares - ICONA, Madrid

Groot, S.P.C. \& Karssen, C.M. -1987- Gibberellins regulate seed germination in tomato by endosperm weakening: a study with gibberellins-deficient mutants Planta 171: 525-531.

Grundy, A.C. \& al. -2003- Modelling the emergence response of weed seeds to burial depth: interactions with seed density, weight and shape - J. Appl. Ecol. 40: 757-770.

Harper, J.L., Lovell, P.H. \& Moore, K.G. -1970 - The shapes and sizes of seeds - Ann. Rev. Ecol. Syst. 1: 327-356.

Hay, F.R. \& Smith, R.D. (Eds.) - 2003- Seed maturity: when to collect seeds from wild plants. Seed conservation: turning science into practice - Kew Royal Botanic Gardens, London.

IUCN $-2002-$ IUCN red list of threatened speciesIUCN, Gland.

Jakobsson, A. \& Eriksson, O. - 2000 - A comparative study of seed number, seed size, seedling size and recruitment in grassland plants - Oikos 88: 494-502.

Johnson, N.L. \& Kotz, S. (Eds.) - 1970- Distributions in Statistics: Continuous Univariate Distributions Vol. 2. - Houghton Mifflin, New York.

Kelly, K.M., Van Staden, J. \& Bell, W.E. -1992 - Seed coat structure and dormancy — Plant Growth Regul. 11: 201-209.

Kikuzawa, K. \& Koyama, H. - 1999- Scaling of soil water absorption by seeds: an experiment using seed analogues - Seed Sci. Res. 9:171-178.

Leishman, M.R., Wright, I.J., Moles, A.T. \& Westoby, M. 2000 - The evolutionary ecology of seed size - In: Fenner M. (Ed.). Seeds, the Ecology of Regeneration in Plant Communities. Pp. 31-58. CABI Publishing, New York.

Lönnberg, K. \& Eriksson, O. -2013- Relationships between intra-specific variation in seed size and recruitment in four species in two contrasting habitats - Plant Biol. 15: 601- 606 .

Marshall, D.R. \& Brown, A.H.D. - 1983- Theory of forage plant collection - In : McIvor J.G. \& Bray, R.A. (Ed.). Genetic resources of forage plants. Pp. 135-148. CSIRO Publishing, Melbourne.

Martin, A.C. - 1946- The comparative internal morphology of seeds - Am. Midl. Nat. 36: 513-660.

Martín-Bravo, S., Valcárcel, V., Vargas, P. \& Luceño, M. 2010- Geographical speciation related to Pleistocene range shifts in the western Mediterranean mountains Taxon 59: 466-482. 
Mattana, E., Pritchard, H.W., Porceddu, M., Stuppy, W.H., Bacchetta G. -2012 - Interchangeable effects of gibberellic acid and temperature on embryo growth, seed germination and epicotyl emergence in Ribes multiflorum ssp. sandalioticum (Grossulariaceae) - Plant Biol. 14: 77-87.

Meyer, S.E. \& Monsen, S.B. -1991- Habitat-correlated variation in mountain big sagebrush (Artemisia tridentata ssp. vaseyana) seed germination patterns - Ecology 72: 739-742.

Mohamed-Yasseen, Y. \& al. - 1994- The role of seed coats in seed viability - Bot. Rev. 60: 426-439.

Moles, A.T., Warton D.I. \& Westoby, M. -2003- Do smallseeded species have higher survival through seed predation than large-seeded species? - Ecology 84: 3148-3161.

Morgan, E.R., Butler, R.M., Bicknell, R.A. -1997- In vitro propagation of Gentiana cerina and Gentiana corymbifera - New Zealand J. Crop Hort. Sci. 25: 1-8.

Murashige, T. \& Skoog, F. - 1962- A revised medium for rapid growth and bioassays with tobacco tissue cultures — Physiol. Plantarum 15: 473-497.

Nikolaeva, M.G. (Ed.) - 1969- Physiology of deed dormancy in seed - lzdatel'stvo 'Nauka' Leningrad.

Norden, N., Daws M.I., Antoine, C., Gonzalez, M.A., Garwood, N.C. \& Chave, J. - 2009- The relationship between seed mass and mean time to germination for 1037 tree species across five tropical forests - Funct. Ecol. 23: 203-210.

Pence,V. - 1999- The application of biotechnology for the conservation of endangered plants - In: Benson, E.E. (Ed.). Plant Conservation Biotechnology, Chapter 15. Pp. 227-241. Taylor and Francis, London.

Pignatti, S. (Ed.) - 1982 - Flora D'Italia - Edagricole, Bologna.

Pizo, M.A., Von Allmen C.L. \& Morellato, P.C. - 2006Seed size variation in the palm Euterpe edulis and the effects of seed predators on germination and seedling survival - Acta Oecol. 29: 311-315.

Rajjou, L., Duval, M., Gallardo, K., Catusse, J., Bally, J., Job, C. \& Job, D. -2012 - Seed Germination and Vigor - Annu. Rev. Plant Biol. 63: 507-33.

Rodriguez Perez, J.A. - 1993-Effects of treatment with gibberellic acid on germination of Protea cynaroides, P. eximia, P. nerifolia and P. repens (Proteaceae) - III International Protea Research Symposium 387: 85-90.

Ruiz-Labourdette, D., Nogués-Bravo, D., Sáinz Ollero, H., Schmitz, M.F., Pineda, F.D.-2012- Forest composition in Mediterranean mountains is projected to shift along the entire elevational gradient under climate change- J. Biogeogr. 39: 162-176.

Sáinz, H. \& Moreno, J.C. - 2002 Flora vascular endémica Española - In: Pineda, F.D. \& al. (Eds.). La diversidad biológica de España. Pp. 175-195. Pearson, Madrid.

Shimono, Y. \& Kudo G. -2005- Comparisons of germination traits of alpine plants between fellfield and snowbed habitats - Ecol. Res. 20: 189-197.
Schlorhaufer, D. - 2006- Alpine Garden Patscherkofel Innsbruck. Alpine Plants in their Environment - University of Innsbruck, Innsbruck.

Schütz, W. \& Milberg, P. - 1997- Seed dormancy in Carex canescens: regional differences and ecological consequences - Oikos 78: 420-428.

Schütz, W. - 2000 - Ecology of seed dormancy and germination in sedges (Carex) - Pers. Plant Ecol. Evol. Syst. 3/1: 67-89

Thanos, C.A. \& Doussi M.A. - 1995- Ecophysiology of seed germination in endemic Labiates of Crete - Isr. J. Plant Sci. 43: 227-237.

Thompson, K., Band S.R. \& Hodgson, J.G. -1993 - Seed size and shape predict persistence in the soil - Funct. Ecol. 7: 236-241.

Thompson, K., Green, A. \& Jewelsh, A.M. -1994 - Seeds in soil and worm casts from a neutral grassland - Funct. Ecol. 8: 29-35.

Thuiller, W., Lavorel, S., Araújo, M.B., Sykes, M.T. \& Prentice, I.C. $-2005-$ Climate change threats to plant diversity in Europe - Proc. Natl. Acad. Sci. U.S.A. 102: 8245-8250.

Tunjai, P. \& Elliott, S. - 2012- Effects of seed traits on the success of direct seeding for restoring southern Thailand's lowland evergreen forest ecosystem - New Forests 43: 319-333.

Urbanska, K.M., Schwank, O. \& Fossati, A. -1979- Variation within Lotus corniculatus L. s. 1. from Switzerland, II. Reproductive behaviour of L. alpinus (DC) Schleicher - Berlin Geobot. Inst. ETH 46: 62-85.

Väre, H., Lampinen, R., Humphries, C., Williams, P. 2003- Taxonomic diversity of vascular plants in the European alpine areas - In: Nagy, L. \& al. (Eds.). Alpine biodiversity in Europe. Ecological studies. Vol 167. Pp. 133-148. Springer, New York.

Weibull, W. - 1951 - A statistical distribution function of wide applicability - J. Appl. Mech. 18: 293-297.

Weber, H., Borisjuk, L. \& Wobus, U. - 1996-Controlling seed development development and seed size in Vicia faba: a role for seed coat-associated invertases and carbohydrate state - Plant J. 10: 823-834.

Werker, E. - 1981 - Seed dormancy as explained by the anatomy of embryo envelopes - Israel J. Bot. 29: 22-44.

Westoby, M. - 1981 - How diversified seed germination behavior is selected-Amer. Naturalist 118: 882-885.

Yamaguchi, S. \& Kamiya, Y. -2002- Gibberellins and light-stimulated seed germination - J. Plant Growth Regul. 20: 369-376.

Youssef, S. \& al. - 2012- Breaking seed dormancy in $\mathrm{Cu}-$ pressus atlantica Gaussen, an endemic and threatened coniferous tree in Morocco - J. For. Res. 23(3): 385-390.

Zuur-Isler, D. - 1982- Germinating behaviour and early life phase of some species from alpine serpentine soils - Berlin Geobot. Inst. ETH 49:76-107. 